\title{
LIGHT AND ELECTRON MICROSCOPE OBSERVA- TIONS AND PREY SPECIFICITIES OF AN ALGOPHOROUS AMOEBA FROM JAPANESE FRESHWATER
}

\author{
YOKO YAMAMOTO AND KENJI SUZUKI* \\ Faculty of Agriculture, Meiji University, Higashimita, Kawasaki \\ *The National Institute of Health, Tokyo, Japan
}

(Received October 19, 1984)

\begin{abstract}
An algophorous amoeba, a species in the genus Nuclearia, was isolated from a eutrophic lake in Japan. The floating form with extremely fine radiating pseudopodia has a mean diameter of $12.5 \mu \mathrm{m}$. The characteristic shape of this isolate is subspherical or flattened and no motile form was observed. The nucleus contains a lobed central nucleolus. Fourteen strains of bacteria, cyanobacteria and green algae were tested as prey for the isolated amoeba. There was considerable variation in the rates of their utilization. The high rates of predation by the amoeba suggest that it may be of importance in the food chains and nutrient recycling in aquatic habitat.
\end{abstract}

The distribution and abundance of amoebae that prey on cyanobacteria and green algae in aquatic habitats are often positively correlated with the distribution and abundance of the primary producer. Examples of such distribution patterns have been reported by CANTER and Lund (1), CooK et al. $(2,3)$ and YAMAmoto (4). Increases in the numbers of amoebae follow those of the prey and the numbers decrease as the population of the primary producer declines.

Some workers have experimented on certain aspects of the feeding behaviour of amoebae (5) and also on the environmental factors that influence the relationship between prey and predator (6). However, little is known about Nuclearia sp. which is common in a eutrophic lake in Japan (4) and is frequently associated with cyanobacterial blooms.

This paper deals with microscopic observations of the Nuclearia isolated from the surface waters of Lake Kasumigaura, and studies of its manner of feeding.

\section{MATERIALS AND METHODS}

Isolation of the amoeba. The method of isolation was similar to that used for the detection of several algal lysing agents by Yамамото (7). Two $\mathrm{ml}$ of MDM agar (made with $100 \mathrm{ml}$ of modified Detmer's medium and $8 \mathrm{~g}$ of agar, $\mathrm{pH} \mathrm{7.5)} \mathrm{at}$ 
Table 1. Media for algal and bacterial culture.

\begin{tabular}{|c|c|}
\hline Organisms & Media \\
\hline Microcystis aeruginosa (IAM-M-176) & $\mathrm{NaCB}$ medium $(9)$ \\
\hline M. elabens $\quad$ (IAM-M-177) & $\mathrm{NaCB}$ medium \\
\hline (IAM-M-178) & $\mathrm{NaCB}$ medium \\
\hline Anacystis nidulans & Modified Detmer's medium (10) \\
\hline Anabaena cylindrica & Modified Detmer's medium \\
\hline Phormidium luridum & Modified Detmer's medium \\
\hline Chlorella pyrenoidosa & Modified Bristol medium (10) \\
\hline $\begin{array}{l}\text { Closterium peracerosum-stigosum- } \\
\text { littorale Complex Group II B }\end{array}$ & CT medium $(8)$ \\
\hline Staurastrum sp. & CT medium \\
\hline Pseudomonas aeruginosa (Ps-8 and -2 ) & Tripticase soy agar \\
\hline Saccharomyces sake & Tripticase soy agar \\
\hline Escherichia coli & Tripticase soy agar \\
\hline
\end{tabular}

$45-48^{\circ}$ was combined with $1 \mathrm{ml}$ of the prey suspension and $0.1-1.0 \mathrm{ml}$ of the lake water. The mixture was then spread over the surface of previously poured MDM agar plates. These double-layered plates were then incubated at $25 / 30^{\circ}$ in light (2,000 lux) for 2 weeks. The plaques that develop on the lawns vary widely in their size and the larger plaques were often found to be caused by amoebae. One of the plaques was placed in $100 \mathrm{ml}$ Erlenmyer flask containing $20 \mathrm{ml}$ of a suspension of the prey for $3-4$ days at $25^{\circ}$ in the light. From this mixed culture the amoeba living on the specific prey was purified by repeated plating on the same prey and cultured in similar liquid culture. Once isolated the amoebae were routinely maintained on slopes of bacteria-free Anabaena cylindrica.

Prey species: source and culture. The cyanobacteria, green algae, fungus and bacteria are listed in Table 1. All of the cyanobacteria and C. pyrenoidosa were from the Culture Collection of Algae at the Institute of Applied Microbiology, University of Tokyo. The Closterium and Staurastrum spp. were obtained from Lake Kasumigaura by ICHIMURA (8) and the Pseudomonas aeruginosa (Ps-2 and Ps-8) and Escherichia coli were kindly donated by Dr. K. Mise. The Saccharomyces sake was from the collection of Meiji University. All the photosynthetic microorganisms were cultured at $28^{\circ}$ in the light $(2,000$ lux $)$ on the media shown in Table 1. The bacteria were kept at $28^{\circ}$ in the dark.

A method for estimating prey specificities. Packed cells $(0.02 \mathrm{ml})$ were spread onto the surface of a Millipore filter (HA) and placed on MDM (10) agar plates. The prey cells used were always cultures of the same age. The amoebae suspension $(0.01 \mathrm{ml})$ was then placed in the center of a filter and the plates incubated at $28^{\circ}$ in the light. The suspension of amoebae $\left(10^{6}-10^{7}\right.$ cells $/ \mathrm{ml}$ at a final concentration) was made in MDM medium. Prey specificities were estimated by measuring the size of the plaques formed on algal lawns after 5 days. The results were recorded the relative size of the diameter, with the largest of the plaques taken to be $100 \%$. All experiments were repeated several times. 
Electron microscopy. The amoeba cells, fed on Anacystis nidulans and Anabaena cylindrica were pre-fixed for $2 \mathrm{hr}$ at $4^{\circ}$ in $1.7 \%$ glutaraldehyde supplemented with $3 \mathrm{~mm} \mathrm{CaCl}_{2}$ and then transferred to $4.5 \%$ glutaraldehyde for $18 \mathrm{hr}$. After washing, the cells were fixed with $2 \% \mathrm{OsO}_{4}$ or with $2 \% \mathrm{KMnO}_{4}$ (aqueous unbuffered) for $2 \mathrm{hr}$ at $4^{\circ}$ and then washed with $3 \mathrm{~mm} \mathrm{CaCl}_{2}$ solution for $2 \mathrm{hr}$. The suspension was dehydrated in ethanol. Specimens for SEM were coated with platinum after drying to the critical point and were then observed under the SEM (S-700, Hitachi). Specimens for TEM were solidified in $1 \%$ agar, cut into small pieces and then embedded in epoxy resin. Sections were then cut with a diamond knife on an LKB Ultrome III. The sections were stained with $2 \%$ uranyl acetate for $2 \mathrm{hr}$ and then with lead citrate for about $10 \mathrm{~min}$ and subsequently viewed under a Hitachi HU-II electron microscope, at $75 \mathrm{kV}$.

\section{RESULTS}

\section{Morphology and structure}

Floating forms of the isolate in liquid medium were subspherical, lobular with variably shaped radiating pseudopodia. The pseudopodia were filiform and not granular. The diameters of 25 floating forms ranged from $9 \mu \mathrm{m}$ to $25 \mu \mathrm{m}$. However, when the same amoebae were feeding actively on the cyanobacteria grown on an agar medium, they were flattened and their surfaces became convoluted (Fig. 2). Their pseudopodia were similar to that of the floating form. The cell was uninucleate and was often orange coloured due to the presence of carotene pigments. There was no obvious hyaline ectoplasm. The ultrastructure of isolate as seen under the TEM is shown in Fig. 1. There was no obvious mucus layer around the cell. The nucleus $(3.67 \pm 0.62 \mu \mathrm{m}$ long), which has a central nucleolus, was lobed and surrounded by a double membrane containing pores $(40 \pm 84 \mathrm{~nm})$. The nucleolus was lobed and contained ribosomal granules like that found in the cytoplasm.

The mitochondria had an oval, elliptical or elongated outline and irregular bili-type cristae. The largest one measured was $1.05 \mu \mathrm{m} \times 0.38 \mu \mathrm{m}$. In active cells the mitochondria were randomly distributed throughout the cytoplasm.

In most sections Golgi bodies were present in various positions. Each Golgi body was composed of a stack of curved centrally flattened cristae. A small number of smooth vesicles was found around the periphery of the stack.

The pseudopodia in section contained cytoplasm of the same nature as that found inside the central mass of the cell (Fig. 1b). Furcate pseudopodia were occasionally observed.

Food vacuoles ranged from one to several micrometers in diameter and larger empty vacuoles were rather few as long as the amoeba was well fed (Fig. 1a). After uptake of the cyanobacterial prey, the food vacuoles contained their cells in differing stages of digestion. A large vacuole measured $8.4 \mu \mathrm{m} \times 6.0 \mu \mathrm{m}$ 

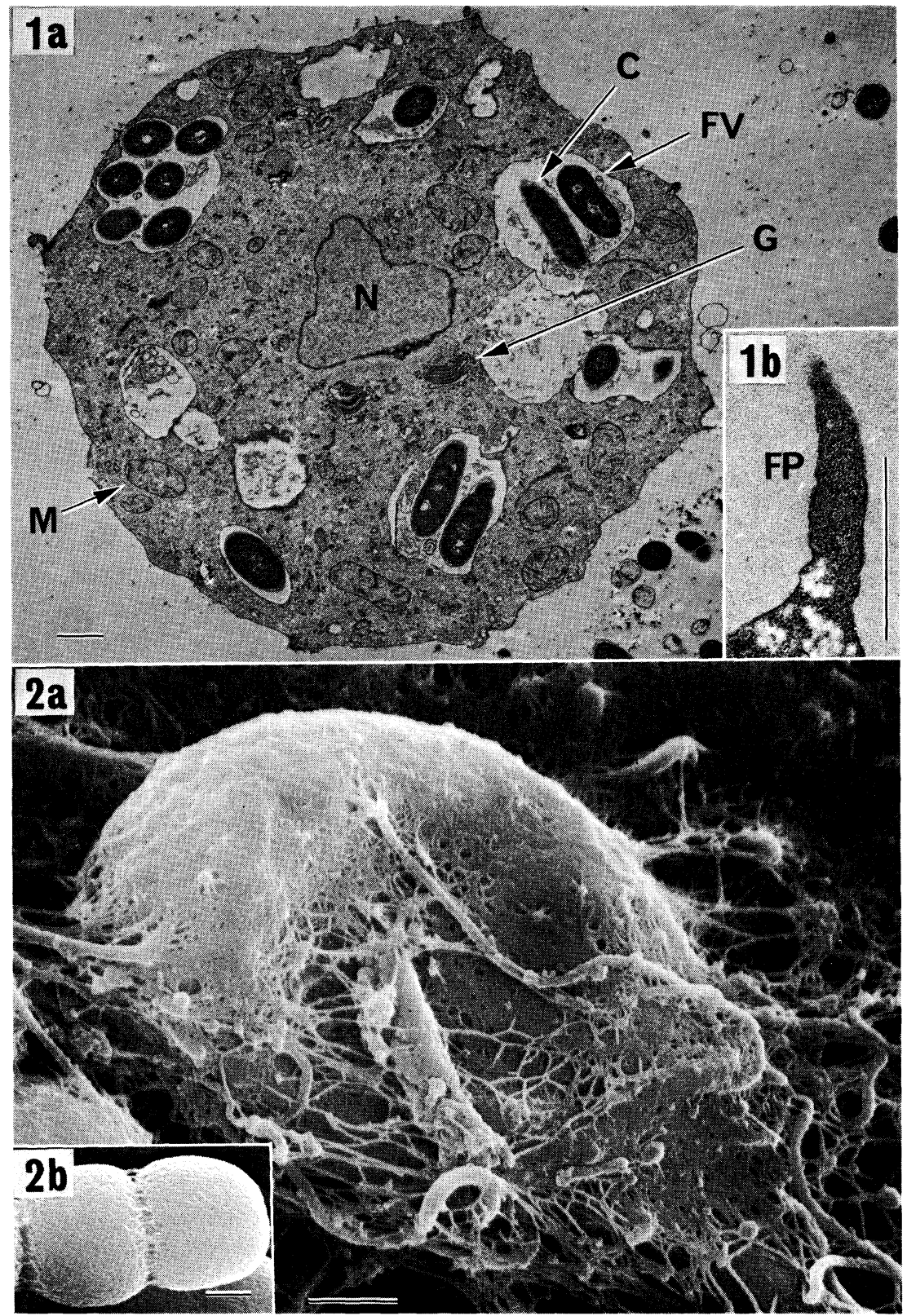

Fig. 1(a). Section of Nuclearia sp. ( $\mathrm{KMnO}_{4}$ fixation)

$\mathrm{C}$ : cyanobacteria, FV: food vacuole, G: Golgi apparatus, $\mathrm{N}$ : nucleus. The marker indicates $1 \mu \mathrm{m}$.

(b). Higher magnification of pseudopodia.

Fine structure shows cytoplasm of the same nature as that found inside the central mass of the cell. FP: pseudopodia. The marker indicates $0.1 \mu \mathrm{m}$.

Fig. 2. Nuclearia sp. fed on Anabaena cylindrica grown on an agar medium.

(a). Scanning electron micrograph of an amoeba with a tuft of pseudopodia attached to the cells of Anabaena cylindrica. The marker indicates $1 \mu \mathrm{m}$. (b). Scanning electron micrograph of a healthy cell of Anabaena cylindrica. The marker indicates $1 \mu \mathrm{m}$. 
Table 2. Prey specificities of amoeba tested on varied strains of alga and bacterium.

\begin{tabular}{|c|c|c|}
\hline Groups & Organisms & $\%$ after 5 day-culture ${ }^{a}$ \\
\hline \multirow[t]{6}{*}{ I } & Microcystis aeruginosa & $75.8 \pm 7.3^{b}$ \\
\hline & M. elabens & $62.8 \pm 7.3$ \\
\hline & M. flos-aquae & $45.3 \pm 4.8$ \\
\hline & Anacystis nidulans & $73.4 \pm 6.7$ \\
\hline & Phormidium luridum & 100 \\
\hline & Anabaena cylindrica & $82.7 \pm 9.7$ \\
\hline \multirow[t]{2}{*}{ II } & $\begin{array}{l}\text { Closterium peracerosum-stigosum-littorale } \\
\text { Complex Group II B }\end{array}$ & $7.8 \pm 1.1$ \\
\hline & Staurastrum $\mathrm{sp}$ & $9.7 \pm 3.7$ \\
\hline \multirow[t]{4}{*}{ III } & Chlorella pyrenoidosa & 0 \\
\hline & Pseudomonas aeruginosa Ps-2 & 0 \\
\hline & Pseudomonas aeruginosa Ps-8 & 0 \\
\hline & Escherichia coli & 0 \\
\hline
\end{tabular}

and contained up to several cells. Closterium and Staurastrum spp. were also eaten. The Nuclearia sp. was attached close to the middle of the algal cell and at this point the cell had a crack. After first puncturing the wall of the algal cell, the amoeba ingest the cell contents. Afterwords, the amoeba released the algal cell, or sometimes it remained in the algal cell. This is the usual manner of feeding in the family Vampyrellidae.

Data on the prey specificities of the amoeba are given in Table 2, the prey species being divided into three groups according to their susceptibility to being eaten by the amoeba. In group I all prey species were eaten. Both unicellular cyanobacteria, the Microcystis spp. and the Anacystis sp. were rapidly engulfed and digested within a few minutes. In M.flos-aquae the slime sheath was not destroyed as shown in Figs. 3a and 3b. Nothing remained of the non-heterocystis $P$. luridum filaments but the heterocysts and akinetes of $A$. cylindrica remained intact after exposure to the amoeba.

In the second group containing the Closterium and Staurastrum spp. the cells were extensively damaged. This was probably brought about by part of the cell wall being broken down and the cell contents being removed by the amoeba (Fig. 4). None of the green algae, bacteria or fungi in group 3 were susceptible to predation so no plaques were formed on their lawns.

\section{DISCUSSION}

The Nuclearia sp. described in this paper is very similar to $N$. simplex described originally in 1865 by Cienkowsky (11) and illustrated by Patterson (12). They had a flattened and subspherical form and a single nucleus with a smooth spherical 

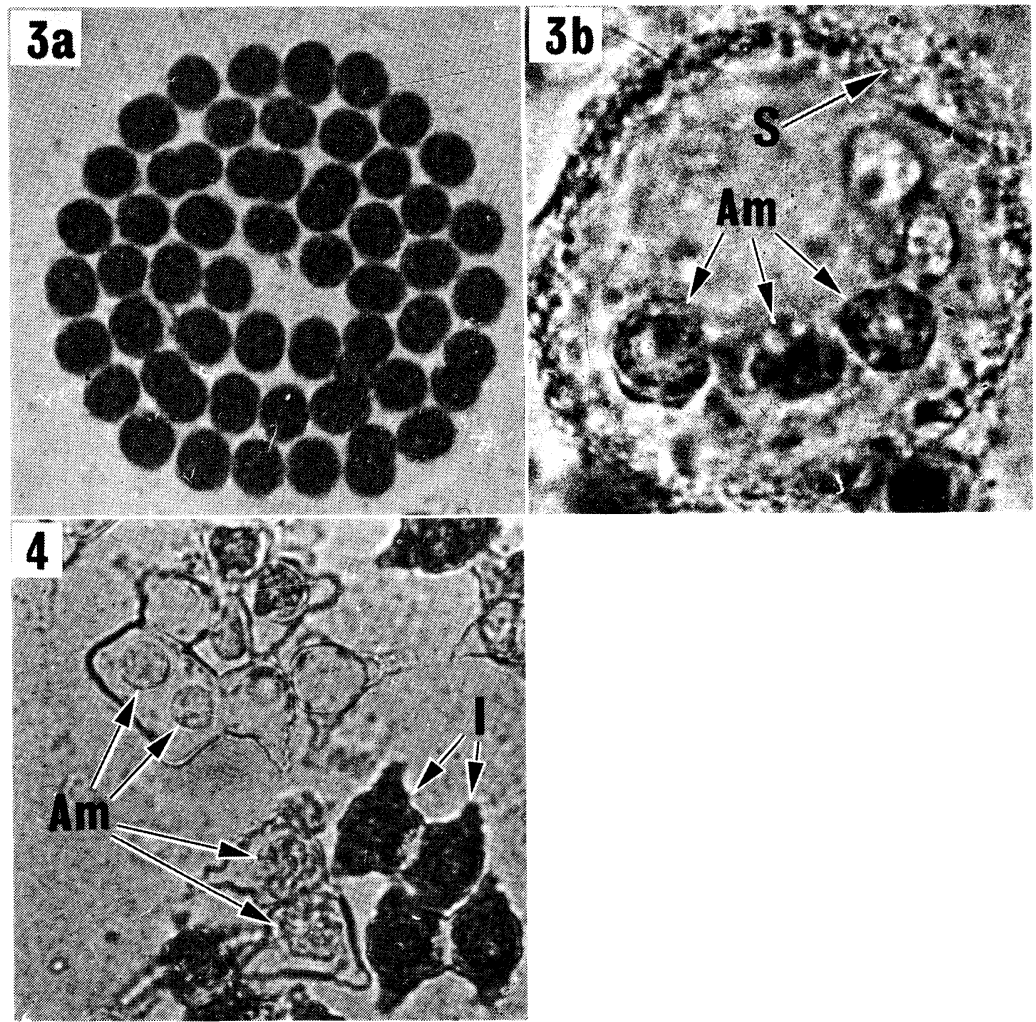

Fig. 3. Intact cells of Microcystis flos-aquae (a) and cells (b) which were attacked by Nuclearia sp.

The surrounding gelatinous sheath remained intact (b). Am, amoeba; S, sheath $(\times 1,200)$.

Fig. 4. Nuclearia sp., which penetrated some portion of the cellulose membrane of Staurastrum, fed on the protoplasmic contents.

The body remnant assumed a cyst-like shape. Am: amoeba, I : intact cell $(\times 400)$.

nucleolus. There was no obvious enveloping mucus sheath around the cell. The cyst-like stage of the isolates resembled the cyst of $N$. simplex $(13,14)$ but was much shorter.

Nucleosphaerium which has a spherical body with radiating filose pseudopodia is also similar to the Nuclearia sp. The organism described by CANN and PAGE (15) has an enveloping mucus sheath, composed of three layers seen after the cells are fixed in $2 \%$ osmium tetroxide. No such mucilaginous coat was observed in the Nuclearia sp. This isolate is also similar to Asterocaelum algophillum (16) and Nuclearia moebiusi(17) which sometimes have branched-pseudopodia and contain orange pigments. However, it differs in the susceptibility of the preysources (Table 2) and in the presence of a cyst-like stage (4). The Nuclearia sp. 
had a subspherical and flattened body and no layer of mucus, like those features of $N$. polypodia (12). $N$. polypodia has no evident nucleolus. Consequently, our isolate does not seem to differ essentially from $N$. simplex although it was considerably smaller, with a mean length of $12.5 \mu \mathrm{m}$.

The relationships among amoeba and their prey species are not well understood. The Nuclearia sp. can feed on the prey by ingesting the long filaments of cyanobacteria. With the green algae such as Closterium and Staurastrum it ingests the cell contents after puncturing the wall of the alga. Food specificities may be related to the differences in the manner of feeding on the respective prey species.

CANNON et al. (18) reported the occurrence of Hartmannella glebae in association with marine algae. They suggested that the amoeba feeds extensively on filamentous cyanobacteria including Plectonema boryanum, Anabaena flos-aquae, Nostoc muscorum and Phormidium tenuis and that amoebae may have an important role in the transport of cyanophage. Microbial interactions in aquatic habitats are complex. The relative importance of each biological system requires understanding if manipulation of the systems can be achieved with regard to the control of nuisance algal blooms.

We wish to express our thanks to Drs. S. Toyama, Ochanomizu University and T. Ichimura, Institute of Applied Microbiology, University of Tokyo, for valuable advice and encouragement during the study. Thanks are also due to Dr. M. J. Daft, Dundee University, U. K., who kindly corrected the English of the manuscript.

\section{REFERENCES}

1) H. M. Canter and J. W. G. Lund, Proc. Linn. Soc., 179, 203 (1968).

2) W. L. Cook, D. G. Ahearn, D. J. Deinhardt and R. J. Reiber, Water Air Soil Pollution, 3, 71 (1974).

3) W. L. Cook and D. G. Ahearn, Distributional History of the Biota of the Southern Appalachians. IV. Algae and fungi, ed. by B. C. PACKer and M. K. RoAN, University Press of Virginia, Charlottesville (1976), p. 71.

4) Y. Yамамото, Jpn. J. Limnol., 42, 20 (1981).

5) T. S. S. Ho and M. Alexander, J. Phycol., 10, 95 (1974).

6) J. Laybourn and L. Whymant, Oecologia (Berl.), 45, 282 (1980).

7) Y. ҮАмамото, Jpn. J. Limnol., 39, 9 (1978).

8) T. Ichimura, Proc. Intl. Seawood Symp., 7, 208 (1971).

9) T. Ichimura and M. M. Watanabe, Bull. Jap. Soc. Phycol., 25, 177 (1977).

10) A. Watanabe, J. Gen. Appl. Microbiol., 6, 283 (1960).

11) L. Cienkowski, Arch. Mikrosk. Anat., 1, 203 (1865) [cited from R. R. Kudo, Protozoology (4th ed.), Charles C. Thomas, Illinois, p. 500 (1971)].

12) D. J. Patterson, Arch. Protistenk., 128, 127 (1984).

13) J. P. Mignot and A. SAvoie, Protistologica, 15, 23 (1979).

14) P. Pernin, Protistologica, 12, 555 (1967).

15) J. P. CAnn and F. C. Page, Arch. Protistenk., 122, 226 (1979).

16) H. M. Canter, Protistologica, 16, 475 (1980).

17) D. J. Patterson, J. Protozool., 30, 301 (1983).

18) R. F. Cannon, M. S. Shane and F. DeMichele, J. Environment. Engineering, 1205 (1974). 